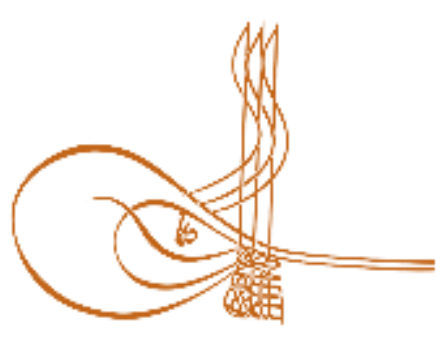

www.turkishstudies.net/social
Turkish Studies - Social Sciences

eISSN: $2667-5617$

Research Article / Araștırma Makalesi

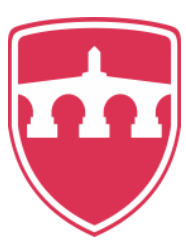

INTERNATIONAL

BALKAN

UNIVERSITY

Sponsored by IBU

\title{
Çocuk Cinsel İstismar Haberlerinin İdeolojik Bakışla Sanal Basındaki Sunumu
}

Presentation of Child Sexual Abuse News in the Virtual Press

\author{
Lokman Cerrah* - Büşra Bazu** - Merve Baran ${ }^{* * *}$
}

\begin{abstract}
Media is the most important means of socialization, communication and self-expression in modern societies. However, they lose their objectivity due to being seen as an important weapon both in their structure and power relations and thus become the ideological devices of the sovereign powers. These sovereign powers also decide everything during the publication and thus choose a language and appropriate words that always affect the reader's perception of news. In recent years, it has been observed that abuse and especially child abuse have increased significantly. Naturally, these news have a significant place in the media. However, due to the reasons mentioned above, the media loses their objectivity in their approach to such news and can present the news in different ways in line with their own ideology or broadcast policy. This study examines how abuse news, which is a vital issue for the individual and society, is presented to the public by the media. In the context of the study, some child abuse news which had a big impact on the country's agenda were analyzed with the title, style and language of each national newspaper that broadcasts online, analyzed with the content analysis technique and inferences were made. As a result, it was revealed that the events evaluated are dealt with biased in these media tools, where the events of their own camp are treated as cursory and defensive and the events of the opposite camp were handled with exaggeration and accusations.
\end{abstract}

Structured Abstract: Any inappropriate words, behaviors or situations that prevent or restrict development are directed to children by an adult as "abuse" (Tiraşçı, Gören, 2007, s.70). Abuse, especially child abuse, can be seen as a crime against an entire society beyond being a crime against a single person. Because

\footnotetext{
${ }^{*}$ Dr. Öğr. Üyesi, Atatürk Üniversitesi, Oltu Beşeri ve Sosyal Bilimler Fakültesi, Sosyal Hizmet Bölümü Asst. Prof. Dr. Atatürk Üniversity, Oltu Faculty of Humanities and Social Sciences, Social Service Deapartment ORCID 0000-0002-7330-4422

lokmancerrah@atauni.edu.tr

** Lisans öğrencisi, Atatürk Üniversitesi, Oltu Beşeri ve Sosyal Bilimler Fakültesi, Sosyal Hizmet Bölümü Bachelor student, Atatürk Üniversity, Oltu Faculty of Humanities and Social Sciences, Social Service Deapartment ORCID 0000-0002-8761-7905

bazuu.68@gmail.com

**** Lisans öğrencisi, Atatürk Üniversitesi, Oltu Beşeri ve Sosyal Bilimler Fakültesi, Sosyal Hizmet Bölümü Bachelor student, Atatürk Üniversity, Oltu Faculty of Humanities and Social Sciences, Social Service Deapartment ORCID 0000-0002-3392-1274

baran.merve@yahoo.com

Cite as/ Atıf: Cerrah, L., Bazu, B., Baran, M. (2020). Çocuk Cinsel istismar haberlerinin ideolojik bakışla sanal basındaki sunumu, Turkish Studies - Social, 15(1), 789-806. https://dx.doi.org/10.29228/TurkishStudies.39464

Received/Geliş: 24 October/Ekim 2019

Checked by plagiarism software

Accepted/Kabul: 25 February/Şubat 2020

Published/Yayın: 29 February/Şubat 2020

Copyright (C) INTAC LTD, Turkey

CC BY-NC 4.0
} 
children are the future of societies. The future promised by individuals who have been abused, unable to survive trauma and whose mental and physical health is impaired will not be a desired future.

Despite being aware of the dangers of child abuse to society for today and for the future, such crimes are occasionally underestimated for personal or ideological reasons. Another reason is the desire to protect the self, even if he is a criminal. As a modern communication tool, virtual media or, with a broader expression, social media is a platform that people from all walks of the society can easily reach, both just follow and actively produce. This platform, which can be easily accessed from anywhere, regardless of age, gender, religion, language, race and economic situation, also has important functions in terms of informing and directing the public. For these reasons, the virtual press was chosen as the tool for presenting such a critical issue for the research. However, since it is not possible to investigate and evaluate all abuse cases in the entire virtual press within such a limited study, the number of cases and virtual press organs has been limited. Abuse case of Former Member of the board of CHP Kuşadası District, Ensar Foundation 10 Boys Rape Incidents and Nesin Foundation abuse Incident were selected as sample cases. Again, virtual press versions of Cumhuriyet, Yeni Akit, Sözcü and Yeni Şafak newspapers were selected as examples of virtual press. These broadcast organs were chosen especially because they had opposing views and ideologies. Cumhuriyet and Sözcü newspapers can be evaluated as left-wing, pro-CHP and AK Party opposition, and Yeni Şafak / Yeni Akit newspapers as conservative, anti-CHP and pro-AK Party.

The purpose of this study is to reveal whether child abuse cases are biased with ideological approaches. The main question of the study is "Is the presentation of child abuse cases objectively made in the virtual versions of the traditional press?"

Content analysis method has been used in the study. Content analysis is a method used in social sciences to investigate social reality in order to reveal the invisible content of transcripts or records obtained from a research as well as the visible content of written or visual media messages by focusing between the lines (Olgun, 2008, S:66; Gökçe, 2006, S:18). The purpose of using this method in our study is presence of numerous written and visual media messages, determining common points which can be answer for the research question among them, and necessity of evaluation. Yet the main purpose in this method is evaluating the common information which is significant in terms of aim of the study by examining and determining numerous text stack (Gökçe, 21). Texts obtained from virtual media has been analyzed by categorising in 5 different title and inferences has been made. These categories can be sorted like that: title, evaluations regarding the perpetraitor; identity of the perpetraitor, picture of the perpetraitor, belonging of the perpetraitor, evaluations regarding the victim; identity of the victim, picture of the victim, belonging of the victim, place, belonging of the place, language; objectivity of the language which was used.

Data obtained as a result of the research has provided opportunity to find answer for the main question of the study significantly "Does presentation of child abuse cases being made objectively to public in virtual version of traditional media?".

Number of news regarding cases related CHP and Nesin foundation,were made in Sözcü/Cumhuriyet newspaper is two, while it's twenty-five regarding Ensar Foundation. Presentation of cases regarding CHP and Nesin Foundation is in the direction of telling the story, concentrating on defence, and even rejecting assertion of case occurrence (last one is just for Nesin Foundation). Contrary to this attitude in the case regarding the Ensar Foundation, it is seen that it is directly against the foundation and the values and institutions that the foundation believes to represent. Usage of expressions from titles to contents such as "rape", "harassment", "abuse" and scandal "are used together to identify with the Ensar Foundation draws the attention. This situation might be evaluated as a result of an ideological view and a case contrary to the acceptance of the media to be objective

It is seen that Yeni Şafak/Yeni Akit newspapers has made fourteen news related to cases of Ensar Foundation, fifteen news related to cases of CHP and Nesin Foundation. Among these newspapers while Yeni Şafak newspaper approached to cases more objectively, it could be seen that Yeni Akit newspaper used a language which identified abuse with Nesin Foundation and CHP. Although both two media organ used condemnatory language, it could be said that they attitudinized protectively.

When the case presentations of both media organs are evaluated together, as a result, it is seen that the ideological perspective is dominant even in such an important issue. This situation damages the perception and belief that the media should be impartial and objective and inform the public correctly.

Turkish Studies - Social, 15(1) 
Keywords: Media, Abuse, Ideology, New Media, Content Analysis

Öz: Medya, modern toplumların en önemli toplumsallaşma, haberleşme ve kendini ifade etme araçlarıdır. Fakat medya, gerek yapısı gerekse güç ilişkileri içerisinde önemli bir silah olarak görülmesi dolayısıyla tarafsızlık ilkesi hayata geçirilememekte ve doğal olarak egemen güçlerin ideolojik aygıtları olarak kalmaktadır. Bu egemen güçler de haber içeriğinden, kelimelerin seçimine, neyin ön planda tutulup, neyin arka planda kalacağına dek her şeye karar vermekte ve böylece okuyucunun haber algısını her zaman etkileyen bir dil ve bu dile uygun kelimeler seçmektedirler. Son yıllarda istismar ve özellikle çocuk istismarının ciddi boyutlarda artış gösterdiği görülmektedir. Doğal olarak bu haberler medyada da kendisine önemli ölçüde yer bulmaktadır. Fakat medya, yukarıda belirtilen sebeplerle bu tür haberlere yaklaşımlarında objektifliklerini kaybetmekte ve kendi ideolojisi veya yayın politikası doğrultusunda haberleri farklı şekillerde sunabilmektedirler. Bu çalışma gerek bireysel gerekse toplumsal açıdan hayati bir mesele olan istismara dair haberlerin yayın organları tarafından topluma nasıl sunulduğunu ortaya koymayı amaçlamaktadır. Çalışma kapsamında çoğunluğu ülke gündeminde büyük yankı oluşturmuş bazı çocuk istismarı haberleri, sanal yayın yapan her bir ulusal gazetedeki başlığı, üslubu ve dili ile incelenmiş, içerik çözümlemesi tekniği ile analiz edilmiş ve çıkarımlar da bulunulmuştur. Sonuçta ise değerlendirilen olayların söz konusu medya araçlarında taraflı olarak ele alındığı, kendi kamplarına ait olayların üstünkörü ve savunu şeklinde ele alındığı karşı kampa ait olayların ise abartı ve suçlamalarla ele alındığı ortaya çıkmıştır.

Anahtar Kelimeler: Medya, istismar, KİA, İdeoloji, Yeni Medya, İçerik Analizi

\section{Giriş}

Teknolojide ki gelişmelerle beraber toplumsal hayat ve toplumsal yapı da büyük ve bir değişim geçirmektedir. İnsan ilişkileri, toplum, toplumsal yapıyı oluşturan her bir parça bu değişimden ayrı ayrı nasibini almaktadır. Önemli değişimlere uğrayan bu toplumsal kurumlardan birisi de medyadır. Medya, geleneksel halini kaybetmiş ve internet tabanlı, interaktif bir yapıya sahip yeni medya kavramsallaştırmasıyla yeni bir forma bürünmüştür. Özellikle tek yönlü ve kontrollü bir yapıya sahip olan geleneksel medyanın aksine yeni medya, hem daha kontrolsüz ve hem de çift yönlü etkileşimi ön plana çıkaran bir özelliğe sahiptir. Yeni medya özellikle ulaşılabilir olma noktasında geleneksel medyadan ayrılmaktadır. Çünkü mobil cihazların kullanılmaya ve medyanın bu cihazlar üzerinden kullanıcıya ulaşmaya başlaması yeni medyayı her kesimden, her yaştan ve her sınıftan insanın hemen hemen her yerden ulaşabileceği ve aktif olarak içerisinde bulanabileceği bir yer haline getirmiştir. Bu sebepten dolayı toplumsal bir olayın, olgunun veya durumun yeni medya da yer alması büyük önem arz eder hale gelmiştir. Özellikle toplumun her kesimini ilgilendiren ve hemen hemen her insanı etkileyen konuların nasıl işlendiği ve topluma nasıl sunulduğu da üzerinde durulması gereken bir mesele olarak karşımızda durmaktadır. Toplumun her kesimini ve her bireyi ilgilendiren ve tabi ki etkileyen konuların en önemlilerinden birisi de çocuk ve çocuk istismarı konusudur. Bu çalışma da işte bu konunun geleneksel medyanın önemli birer örneği olan gazetelerin yeni medya üzerinde yer alan sayfalarında çocuk istismarı konusunun nasıl işlendiğini ele almaktadır.

\section{I.Bölüm}

\section{Kavrmasal Çerçeve}

\section{Çocuk, İstismar ve İstismarın Çeşitleri}

Çocuk istismarının Türkiye'de yaygın toplumsal sorun olarak ele alınmaya başlaması ancak son on yılda gerçekleşmiş olup bu konuda yapılan birçok araştırma Türkiye'deki çocukların \%13.9-87'sinin fiziksel istismara uğradığını göstermiştir (Ayvaz, Aksoy, 2004, s.28). Çocuk istismarının ortaya çıkmasına sebep olabilecek pek çok durum söz konusudur. Bunlar mikro, mezzo ve makro düzeyde ele alınabilir. Mikro düzeyde sebepler olarak otorite kullanımı, alkol/madde kullanımı, ebeveyni ayrı aile, genç yaşta anne olma, sosyal izolasyon, ailenin kalabalık olması, 
düşük sosyoekonomik düzey, ebeveynlerde çocuklukta psikiyatrik hastalık ve ailede çocukta istismara uğrama öyküsü bulunması sayılabilir. Mezzo düzeyde yaşanılan sosyal çevre ve makro düzeyde de çocukları koruyan yasaların yetersiz olması, toplumdaki sosyal eşitsizlikler, savaşlar, silahlanma ve medyadaki şiddet gibi faktörler sayılabilir (Güner, Güner, Şahan, 2010, S.108).

Konunun daha iyi anlaşılması için bazı kavramların kısaca açıklanması gerekmektedir.

$\mathrm{Bu}$ kavramlardan ilki şüphesiz çocuk kavramıdır. Birleşmiş Milletler Çocuk Hakları Sözleşmesi'ne göre 18 yaşın altındaki herkes çocuk olarak tanımlanır (Birleşmiş Milletler Çocuk Hakları Sözleşmesi [BMÇHS], Madde:1). Sözleşmeye taraf devlet olması sebebiyle Türk hukuk sistemi de çocuğu bu kapsamda tanımlar (5395 Sayılı Çocuk Koruma Kanunu, madde:3). Tarihsel sürece baktığımızda ise çocuk kavramının, çocuğa bakış açısının zaman, kültür gibi unsurlara bağlı olarak değiş̧iklik gösterdiği görülür. Çocuk üzerinde mutlak bir otorite olarak ilk çağlarda kendini gösteren anlayış, değişim geçirerek 21.yüzyılda çocuğu merkez alan ve bir birey olarak ona sayg1 duyan bir anlayışa dönüşmüştür." (Sağla, Aral, 2016, s.47).

Çocuk istismarı: Anne, baba ya da bakıcı gibi bir erişkin tarafından çocuğa yöneltilen, toplumsal kurallar ve profesyonel kişilerce uygunsuz ya da hasar verici olarak nitelendirilen, çocuğun gelişimini engelleyen ya da kısitlayan eylem ve eylemsizliklerin tümü olarak tanımlanır (Tıraşçı, Gören, 2007, s.70). Dünya Sağlık Örgütünün, 1985 yılındaki tanımına göre de; çocuğun sağlığını, fiziksel gelişimini, psiko-sosyal gelişimini olumsuz yönde etkileyen bir yetişkin, toplum veya ülkesi tarafından bilerek veya bilmeyerek yapılan davranışlar, çocuk istismarı olarak kabul edilir. (Özdemir, 2012, s.40). Yapılan bir araştırma da çalışmada annelerin ifadelerine göre,

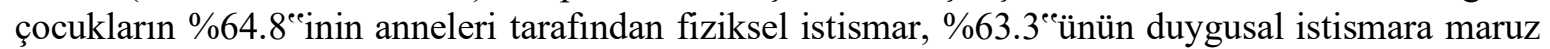
kaldıkları belirlenmiştir (Altıparmak, Yıldırım, Yardımcı, 2013, s.359). Çocuk istismarı 4 başlık altında çeşitlendirilerek ele alınır. Bunlar; Fiziksel İstismar, Cinsel istismar, Duygusal İstismar ve ihmal olarak sıralanabilir.

Fiziksel İstismar: Fiziksel istismar, bir kaza olmaksızın, fiziksel travma ya da yaralanmalarla sonuçlanan herhangi bir davranış biçimi' olarak tanımlanır. Tanımdan da anlaşılacağ 1 üzere yaralanmaların sıklığı, sebebi, kaza sonucu olup olmayacağ 1 ve yaş ile paralel olup olmaması durumu istismar niteliği taşıyıp taşımadığının değerlendirilmesinde belirleyicidir. Yapılan araştırmalarda fiziksel istismara uğrama ihtimalleri değerlendirildiğinde, cinsiyet açısından bir fark bulunmadığı ama yaşın önemli bir fark yarattığı ortaya çıkmaktadır. Örnek olarak en çok 48 yaş grubunda görülen fiziksel istismarın yaşla birlikte azaldığı görülmektedir Taner, Gökler, 2004,). Fiziksel istismar tanınması en kolay olan istismar olup, sadece çocuğun kaza dışı fiziksel olarak zedelenmesi olmayıp aynı zamanda onu duygusal olarak da yıpratmaktadır (Güler, Uzun, Boztaş, Aydoğan, 2012, S.129). Fiziksel istismarın vücut üzerindeki bulguları sıyrıklar, kırıklar, yanıklar ve lezyonlar olup çoğunlukla olaydan uzun süre sonra durumunun kötüye gitmesi ve ailenin bundan korkması nedeniyle ilk olarak acil servise getirilirler (Pelendecioğlu, Bulut, 2009, s.55).

Cinsel İstismar: Cinsel istismar, cinsel gelişimini tamamlamamış bir çocuk veya ergen için, bir erişkin tarafindan zorlanarak veya ikna (İşeri, 2008, s:7) ile cinsel açıdan olgun bir yetişkinin cinsel doyumuna yol açacak bir eylem içerisinde yer alması veya bu duruma göz yumulması olarak tanımlanmaktadır (Ar, 2017). Bununla birlikte eğer iki çocuk arasındaki cinsel aktiviteler; yaş farkı en az 5 yıl ise ve küçük çocuk zorlama ya da ikna ile cinsel haz amacı güden aktivitelere maruz bırakılmış ise bu durumda da vaka, cinsel istismar olarak ele alınır (Alparslan, 2014, s.194).

Cinsel istismar toplumda, çoğunlukla gizli kalmakta, en çok yüzde 5-10'u ortaya çıkmaktadır (Ar, 2017). Bunun nedeni, mağdur olan olguların istismarı açıklamaya korkmaları olabileceği gibi, adli sürecin uzun ve karmaşık yapısı da olabilir (Bilginer, Hesapçıŏlu, Kandil, 2013, s.62). Dünya Sağlık Örgütü ve Ankara Üniversitesi’nin hazırladığı Türkiye'de Üniversite 
Öğrencilerinde Çocukluk Çağı Olumsuz Yaşam Deneyimleri Araştırması Raporuna göre; Cinsel tacize uğrayan çocukların tacizcilerinin kim olduğu sorusuna verdikleri cevaplara bakıldığında bunların çoğunluğunun çocukların tanıdığı kişiler olması dikkat çekmektedir. ${ }^{1}$

Cinsel istismar, çocuklarda hayatlarının sonuna kadar unutamayacakları ve onları her daim zorlayacak pek çok olumsuz etki yaratmaktadır. Çünkü çocuklar cinsel istismar açısından en korunmasız grubu oluşturmakta ve bu olaydan sadece mağdurlar değil, mağdurların yakın çevreleri de etkilenmektedir (Alpaslan, 2014, s.199).

"Cinsel istismara uğramış çocukların gelişimleri ve psikolojileri zedelenmekte ve bu çocuklarda korkular, fobiler, içine kapanma, suçluluk duygusu, depresyon, intihar düşüncesi, iştahsızlık, psikosomatik bozukluklar, güvensizlik, okul problemleri, düşük benlik duygusu, alkol ve uyuşturucu bağımlılığ ortaya çıkmaktadır." (Özdemir, 2012, s.45). Çocuklar açısından bakıldığında kısa süre içinde ortaya çıkabilen kaygı bozukluğu, uyku bozuklukları, kâbuslar, fobiler, Dikkat eksikliği ve hiperaktivite bozukluğu, amnezi, aşırı fantezi kurma, trans benzeri durumlar ve uyurgezerlik, yüksek oranda depresyon, intihar düşünceleri ve girişimleri, Öfke tepkileri, zayıf dürtü kontrolü, genellikle yalnızlıkla sonlanan ilişki kurma denemeleri, daha fazla oranda ergenlik çağında gebe kalma, birden fazla cinsel eş, korunmasız cinsel ilişki ve cinsel yolla bulaşan hastalıkların sıklığı, daha fazla cinsel saldırıda bulunma ihtimali (Taner, Gökler, 2014, s.84)

Finkelhor cinsel istismarın çocuk üzerinde ki etkilerini şu şekilde açıklamaktadır; Çocuğun sağlıklı ve normal olmayan bir cinsel gelişme göstermesi, ilişkilerinde güven ve bağlllık konularında sorunlar, kaygı, korku ve çaresizlik gibi ağır duygular yaşaması ve kendine zarar verici davranışlar geliştirmesi Suçlama (stigmatization), düşmanca davranışlar geliştirmesi ve böylece suça yönelmesine neden olur (.Finkelho, Browne, 1985).

Duygusal İstismar: Çocuk ve gençlerin, psikolojik gelişmenin duraklamasına neden olacak sözel istismarı veya aşırı emirleri kapsayan, gereksinim duydukları ilgi, sevgi ve bakımdan mahrum bırakılarak, çocuğun kimliğini zedeleyen ve bozuk davranışları ortaya çıkaran tavırları içeren bir süreç olarak değerlendirilir (Şimşek, Cenkseven, Önder, 2011, s.1124). Aynı zamanda sosyal ve bilimsel standartlara göre ruhsal yönden hasara uğratılmaları durumu olup en sik rastlanılan istismar türlerinden olmasına karşın adlandırması çok zordur (Kanak, 2011). Duygusal istismar tüm istismar biçimleri ile beraber bulunabilen ve yine tamamını bir şemsiye gibi altında toplayan bir olgu olmasının yanında fiziksel ve cinsel istismarın somut hasarı, izleri yok olduktan sonra da duygusal istismar devam etmektedir (Erkman, 1999, s.127). Çok sayıda ve farkl111kta duygusal istismar türü bulunmaktadır. Bunlardan bazıları reddetme, aşağılama, ayırma, yalnız bırakma, yıldırma, korkutma, kışkırtma, görmemezlikten gelme, duygusal ihtiyaçlarına cevap vermeme, zihinsel sağlık, tıbbi ve eğitimsel ihmal yaş ve gelişimsel yönden çocuktan kapasitesinin çok üstünde beklenti içinde olma "şeklinde sayılabilir (Yavuzer, 1995, s.58).

İhmal: İhmal, çocuğun yaşamsal gereksinimlerinin çocuğa bakmakla yükümlü kişi veya kişiler tarafından, daha geniş anlamda sağlık, eğitim, sosyal yardım ve güvenlik gibi kurumları yapısında bulunduran devlet tarafindan karşılanmaması anlamına gelir (Kara, Biçer, Gökalp, 2004, s.144). Fiziksel istismar aktif bir olgu iken ihmal pasif bir olgudur (Ayvaz, Aksoy, 2004, s.27).

\section{Medya Ve Çeşitleri}

Kitle iletişim araçları yerine kullanılan medya kavramı ile kitlesel iletişimi sağlayan çok sayıda ve farklılıkta araç kastedilmektedir. Medya, TCK'da da iletişim ortamı ve iletişim araçları

1 Detaylı bilgi için bknz: Çocuk istismarına yönelik rapor, 2016, İMDAT | Şiddeti Önleme ve Rehabilitasyon Derneği \& ASUMA | Acıbadem Üniversitesi Suç ve Şiddetle Mücadele Uygulama ve Araştırma Merkezi 
olarak tanımlanırken ${ }^{2}$ organizasyon yapısı bakımından da büyük ölçekli ticari şirketler olarak karşımıza çıkmaktadır ${ }^{3}$.

Medya yani kitle iletişim araçları, toplumsal değişim sürecine hem doğrudan etki etme hem de çeşitli ürünler aracılığı ile iletileri topluma aktarma özelliği olan araçlardır (C1lızoğlu, 2011, s.91). Özellikle iletişim teknolojilerinde ki gelişim ve küreselleşmenin yarattı̆̆ mekân ve zaman sınırlarının ortadan kalkması durumu medyanın etkinlik alanının genişlemesine ve sözlü, yazılı, basılı ve görsel materyallerle daha çok hedef kitleye ulaşmasına yol açmıştır." (Doğrucan, Yıldırım, 2011, s.180). Mesela yapılan bir araştırmada gençliğe kendilerini etkileyen en önemli kurumun hangisi olduğu sorulmuş, aile ilk sırada, medya ikinci sırada ve okul yani eğitim kurumları üçüncü sırada yer almıştır (Kocadaş, 2002,s.207). Kitlelere hitap etmesi ve onları bu derece etkilemesi medyanın işlevleri dolayısıyla gerçekleşmektedir. Bu işlevler, haber, eğitim ve kültür verme, eğlendirme, tanıtım, propaganda ve reklam işlevleri olarak sıralanabilir (Aziz, 2010, s.102).

Medya tarihsel süreçte farklı özellikler kazanarak ve farklı formlara bürünerek önemli bir değişim dönüşüm geçirmiştir. Bu gün itibariyle baktığımızda medya özellikleri ve platformları dikkate alınıp "geleneksel medya" ve "yeni medya" olarak ikiye ayrılarak değerlendirilmektedir.

Geleneksel medya matbaanın icat edilerek ilk kitabın basıldığı 1450'li yıllardan (Aziz, 2010, s.105) internetin icat edildiği tarihe kadar geçen süreçte var olan medya çeşididir. Geleneksel medyanın ortak özelliklerinden bazılar tek yönlü iletişime müsait olması, bir sahipliklerinin olması, pahalı ve teknolojik olarak ağır araç gereçlere sahip olmak zorunda olmaları ve profesyonel elemanlara ihtiyaç duymaları sayılabilir. Geleneksel medya örnekleri arasında matbaa, gazete, dergi, radyo, televizyon ve sinema say1labilir.

Yeni medya ise internet medyacılığ ad$_{1}$ ile de bilinir ve geleneksel medyadan birçok özelliği ile ayrışır. Bu kavram ile dijital kodlama sistemine temellenen, iletişim sürecinin aktörleri arasında eş zamanlı ve yoğun bir kapasitede, yüksek hızda, karşılıklı ve çok katmanlı etkileşimin gerçekleştiği multimedya biçimselliğine sahip iletişim araçları kastedilir (Binark, 2007, s.5). Yeni medyanın örnekleri olarak Facebook, Twitter, İnstagram, Youtube ve benzeri sosyal paylaşım siteleri ile internet üzerinden yayın yapan her türlü haber ve paylaşım siteleri gösterilebilir. Sosyal paylaşım yeni medyanın ayırt edici bütün özelliklerini göstermekte ve, bireylerin; sınırlı bir sistemde dışarı açık ya da yarı açık bir profil oluşturmalarına, aynı sistem içerisinde bağlantıda oldukları diğer kullanıcıların profillerini listelemelerine, kendilerinin ya da sistem içerisindeki diğer kullanıcıların oluşturdukları bağlantı listelerine bakmalarına ve takip etmelerine imkan veren "web" tabanlı servisler olarak tanımlanmaktadır (Danah, Ellison, 2007).

Fakat yeni medyanın ortaya çıkışı geleneksel medyanın tamamen etkisini yitirdiği anlamına gelmemekte aksine geleneksel medya yeni şartlara uyum sağlayarak internet medyası ile etkileşime girmiş ve böylece yeni formlar ve kavramlar ortaya çıkmıştır. Mesela internet gazeteciliği, çoğu geleneksel gazetenin internet ortamında yayınını sürdürmesiyle ve aynı zamanda sadece internet üzerinden yayın yapan sitelerin var olmasıyla ortaya çıkmış ve işlerlik kazanmıştır (Demirel, 2018, s.827).

\section{Medya ve İdeolojik Boyut}

Medyanın haberlerde kullandığı dil ve seçtiği kelimeler okuyucunun haber algısını her zaman etkileyen bir araç olmuştur. Bu durum öözellikle kamuoyu için bıçak sırtı olarak tarif edilebilecek hassas konular, algılarda endişe oluşturabilecek hususlar, kısacası ülke gündemini sarsacak haberlerde daha açık bir şekilde görülmektedir (Bozkanat, 2013, s.3). Bunun en önemli

2 http://www.tdk.gov.tr/index.php?option=com_bts\&arama=kelime\&guid=TDK.GTS.5c78202156f522.60120595 (E.T. 28.02.19)

3 http://www.iletisimvediplomasi.com/medya-okuryazarligi-prof-dr-zakir-avsar/ 
sebepleri olarak haberin ortaya çıkış sürecinde ve haber dilinin kurulmasında habercinin sübjektif olabilmesi ve habercinin bünyesinde çalıştığı medya organizasyonu gösterilebilir. Çünkü her medya organizasyonunun gerek ideolojik gerekse haberin yazımına dair kendine özgü bir üslubu söz konusudur (Yurdigül, Zinderen, 2012, s.83). Özellikle haber dilinin oluşturulması sürecinde, medya metinlerinde özne kullanımı ideolojik yansımanın önemli bir göstergesi olabilir. Yani elit ya da güçlü grupların, olumsuz eylemleri söz konusu olduğunda özne hiç metinde yer almayabileceği gibi pasif yapı formunda da kullanılmış olabilir. Dijk'e göre "özne kullanımı", cümle yapılarının, ideolojik pozisyonun örtüsü altında da açıklanabileceğini kanıtlar. Hatta sadece özne kullanımı değil aynı zamanda habere ayrılan yer ya da zaman, dilin vurgu sistemi, kullanılan cümlelerin yapısı, seçilen yüklemeler, zarflara sıfatlara ayrılan yerler, bunların hepsi birer ideolojik seçimdir (Özerkan, s.67).

Konjonktürel kırılmalarla beraber basın-iktidar ve basın-sermaye ilişkilerinin özerk olmaması sebebiyle bağımsız enformasyon ortamı bir türlü gerçekleşememekte ve bunun sonucunda ise kitle iletişim araçları da çoğunlukla egemen güçlerin ideolojik aygitları olmaktan öteye gidememektedir (Güneş, 2006, s.90). Chomsky ve Herman'a göre medya kendisini denetleyen ve finanse eden güçlü toplumsal grupların çıkarlarına hizmet eder (Chomsky, Herman, 2012, S.15). Aynı şekilde Çiler Dursun'da, haberlerin tarafsız olmadığı, var olan bir egemen görüş ve sınıf çerçevesinde kurgulandığı, bu egemen görüşün sermayesini gözetlediği, kitle iletişim sistem sermayedarlarının kapitalist bir sistem içerisinde hareket ettiği, bu ilișkiler nedeniyle haberlerin tarafsız, saf haber metinlerinden ibaret olamayacağını vurgulamaktadır (Özdemir, s.45). Chomsky'nin güç odakları diye nitelediği egemen görüş ve sınıflar, haber içeriğinden, kelimelerin seçimine, neyin ön planda tutulup, neyin arka planda kalacağına dek her şeye karar vermektedir (Bozkanat, s.İ).

\section{Bölüm}

Çalışma da içerik analizi yöntemi kullanılmıştır. İçerik analizi, sosyal bilimlerde gerek bir araştırma sonucu elde edilen transkript ya da kayıtların, gerek de yazılı veya görsel medya mesajlarının (Olgun, 2008, s:66) görünür içeriğinin dışında satır aralarına odaklanılarak görünmeyen içeriğinin ortaya çıkarılmasını sağlamak amacıyla kullanılan ve bu yolla sosyal gerçeği araştıran bir yöntemdir (Gökçe, 2006, s:18). Çalışmamızda bu yöntemin kullanılmasının temel sebebi çok sayıda yazılı ve görsel medya mesajının varlığı ve bunlar arasından araştırma sorusuna cevap teşkil edecek ortak noktaları saptama ve değerlendirme gerekliliğidir. Zira bu yöntemin de temel amaç, çok sayıda ki metin yığınını inceleyerek araştırmanın amacı açısında önemli olan ortak bilgileri saptayarak değerlendirmektir (Gökçe, 2006, s: 21). Araştırma konusu olarak toplumda yankı uyandıran ve genelde kutuplaşmalara yol açan, ideolojilerin daha net ortaya konulduğu dini, siyasi ve ideolojik tutumların muhatabı olan çocuk cinsel istismarı haberleri seçilmiştir. Bu olaylara ait haberlerin incelenmesi amacıyla özellikle farklı ve birbirine zıt ideoloji veya zihniyete sahip yayın organları seçilmiş ve bu yayın organlarında farklı zamanlarda toplumda infial yaratacak derecede etki uyandırmış üç ayrı olay değerlendirmeye alınmıştır. Belirlenen üç olayın Cumhuriyet, Yeni Akit, Sözcü, Yeni Şafak gazetelerinin sanal basındaki örneklerinden alınmıştır. Bu üç olayın her biri ayrı ayrı altı kategori açısından incelenmiş ve bu yayın organlarının bu olayları topluma nasıl sundukları tespit edilmeye çalışılmıştır. Bu kategorileri şu şekilde siralayabiliriz;

\section{Başlik}

2. Faille ilgili değerlendirmeler; failin kimliği, resmi, aidiyeti

3. Mağdurla ilgili değerlendirmeler; mağdurun kimliği, resmi, aidiyeti

4. Mekân; mekânın aidiyeti

5. Dil; kullanılan dilin tarafsızlığ 


\section{Bulgular ve Değerlendirme \\ 1)CHP Kuşadası İlçe Yönetim Kurulu Eski Üyesi Taciz Olayı}

Sözcü Gazetesi: CHP Kuşadası + taciz olayı + Sözcü” ifadeleriyle Google'da yaptığımız taramada sadece bir tane haberin yapıldığı görülmüştür.

"CHP'li eski yönetici, tacizden tutuklandı"

Haber başlığında sanıkla ilgili doğrudan aidiyet içeren bir ifade kullanıldığı görülmektedir. Metin içerisinde failin ismi açıkça belirtilmeyip isminin baş harflerini yazılmış, failin fotoğrafinda yüzünü tam gösterilmemiş resmi bulanıklaştırılmış ve CHP'ne mensup olduğunu açıkça yazılmıştır. Mağdurla ilgili olarak ismi açıkça belirtilmeyip sadece isminin baş harfleri yazılmış, yaşının 14 olduğunu belirtilmiş ve mağdurla ilgili hiç bir fotoğraf kullanılmamıştır. Olayın geçtiği otobüsün CHP parti üyelerine ait olduğu açıkça belirtilmiştir. Olaya sessiz kalmayanların parti üyesi olduğunu vurgulayıcı bir dil kullanılmıştır. Aynı zamanda Partinin suçlanan şahsı ihraç ettiği alt başlık olarak verilmiş. Fakat özellikle olaya şahit olanların, CHP İlçe başkanının olayı örtbas etmeye çalıştığını iddia ettiğini dile getirilmiştir. Gazete haberinde sanık hakkında yakalama kararı çıkarıldığını ve otobüsle seyahat halinde iken yakalandığını dile getirmiş. Ayrıca sanığın hakkında ki suçlamaları reddettiğine de haber metninde yer verilmiştir.

Cumhuriyet Gazetesi: “CHP Kuşadası + taciz olayı + Cumhuriyet" ifadeleriyle Google'da yaptığımız taramada sadece bir tane haberin yapıldığı görülmüş̧ür.

"CHP tacizin üzerini örtmedi, partiden ihraç etti"

Haberde başlık olarak CHP'yi koruyucu bir ifade kullanıldığı görülmektedir. Haber metninde ise bu olay ele alınırken failin ismi açıkça belirtilmeyip isminin baş harfleri yazılmış failin fotoğrafı net olarak gösterilmiştir. CHP'ye mensup olduğu açıkça yazılmıştır. Mağdurla ilgili ismi açıkça belirtilmeyip sadece isminin baş harfleri yazılmış yaşının 14 olduğunu belirtilmiş ve mağdurla ilgili hiç bir fotoğraf kullanılmamıştır. Olayın geçtiği otobüsün CHP parti üyelerine ait olduğu açıkça belirtilmiştir. Fakat özellikle olaya şahit olanların, CHP İlçe başkanının olayı örtbas etmeye çalıştığını iddia ettiğini dile getirilmiştir. Ayrıca haber metninde olayla ilgisi olmadığ halde bir başka haberin linki özellikle haberin ortasına yerleştirilerek algı yönlendirme çalışması yapıldığı görülmektedir. Bu linkte "AKP 'Çocuk İstismarı için komisyon' önerisini reddetti”' cümlesini kullanılarak dikkatler başka partiye çekilmeye çalışılmıştır.

Yeni Şafak Gazetesi: “CHP Kuşadası + taciz olayı + Yeni Şafak” ifadeleriyle Google'da yaptığımız taramada sadece bir tane haberin yapıldığı görülmüştür.

“CHP'li yönetici çocuğa taciz iddiasılla tutuklandı"

Haber başlığında sanığın CHP ilişkisi doğrudan verilmiş fakat bu ilişkinin eski olduğu ifade edilmemiştir. Haber metninde ise bu olay ele alınırken failin ismi açıkça belirtilmeyip isminin baş harfleri yazılmış, fotoğrafi net bir şekilde gösterilmiştir. CHP'ye mensup olduğunu açıkça yazılmıştır. Mağdurla ilgili ismi açıkça belirtilmeyip sadece isminin baş harfleri yazılmış yaşının 14 olduğu mağdurun ailesinin maddi durumunun iyi olmadığı belirtilmiş ve mağdurla ilgili hiç bir fotoğraf kullanılmamıştır. Olayın geçtiği otobüsün CHP üyelerine ait olduğu açıkça belirtilmiştir. Olay yalın ve aidiyetleri vurgulayan bir üslupla anlatılmıştır. Aynı zamanda Partinin suçlanan şahsı ihraç ettiği alt başlık olarak verilmiş. Fakat özellikle olaya şahit olanların, CHP İlçe başkanının olayı örtbas etmeye çalıştığını iddia ettiği dile getirilmiştir. Gazete haberinde sanık hakkında yakalama kararı çıkarıldığını ve otobüsle seyahat halinde iken yakalandığı anlatılmış. Ayrıca sanığın hakkında ki suçlamaları reddettiğine de haber metninde yer verilmiştir. Fakat haber içerisinde ara başlık olarak "Kaçmaya çalışırken yakalandı" cümlesinin kullanıldığı da dikkat çekmektedir. 
Yeni Akit Gazetesi: “CHP Kuşadası + taciz olayı + Yeni Akit” Google'da yaptı̆̆ımız taramada ifadeleriyle Google'da yaptığımız taramada üç tane haberin yapıldığı görülmüştür. Bunlar:

"CHP otobüsünde cinsel saldırı! 13 yaşındaki..." , "CHP otobüsündeki skandal büyüyor",5 ve "CHP'li sapık çocuğa tacizden tutuklandı!” haberleridir.

Haber başlıklarında "taciz" ve "CHP" ifadelerinin beraber kullanıldığı ve bu yöntemle bir özdeşleştirme çabasının olduğu görülmektedir.

Haber metinlerine bakıldığında ise; Pedofili skandalı ifadesinin sık sık içerisinde geçtiği ilk haber metninde özellikle olayın yaşanma süreci ele alınmaktadır. Her iki haberde de alkol içilmesi sonucu yaşandığ verilmediği bilgisi yer almaktadır. Özellikle ilçe başkanının olayı örtbas etmeye çalıştı̆̆ 1 ve genel merkez incelemesi sonucunda da bu şahsa herhangi bir ceza verilmediği dile getirilerek korunduğu izlenimi verilmektedir. Diğer partililerin olaya sessiz kalmadığ 1 ve ifadeleriyle durumu açıklığa kavuşturdukları anlatılmaktadır. İkinci haberde özellikle "alkol", "CHP" ve "taciz" kelimelerinin birlikte geçtiği bir bölümün metnin tamamına göre daha kalın bir font ile verilmesi dikkat çekmektedir.

Haberler genel olarak olayı ele alırken failin ismi açıkça belirtilmeyip isminin baş harfleri yazılmış failin fotoğrafı net olarak gösterilmiştir. CHP'ye mensup olduğunu açıkça yazılmıştır. Mağdurla ilgili ismi açıkça belirtilmeyip sadece isminin baş harfleri yazılmış yaşının 14 olduğu mağdurun ailesinin maddi durumunun iyi olmadığı belirtilmiş ve mağdurla ilgili hiç bir fotoğraf kullanılmamıştır. Olayın geçtiği otobüsün CHP üyelerine ait olduğu açıkça belirtilmiştir. Olay aidiyeti vurgulayan bir üslupla anlatılmıştır. Aynı zamanda Partinin suçlanan şahsı ihraç ettiği alt başlık olarak verilmiş. Fakat özellikle olaya şahit olanların, CHP İlçe başkanının olayı örtbas etmeye çalıştığını iddia ettiğini dile getirilmiştir. Gazete haberinde sanık hakkında yakalama kararı çıkarıldığı ve otobüsle seyahat halinde iken yakalandığı dile getirilmiş. Ayrıca sanığın hakkında ki suçlamaları reddettiğine de haber metninde yer verilmiştir.

\section{2)Ensar Vakfı 10 Erkek Çocuğa Tecavüz Olayı}

Sözcü Gazetesi: "Ensar Vakf1 + taciz olay1 + Sözcü" Google'da yaptı̆̆ımız taramada ifadeleriyle Google' da yaptığımız taramada on tane haberin yapıldığg görülmüştür. Bunlar:

"Tecavüze uğrayan bebeler mi Ensar Vakfi mı korunmaya muhtaç?”, " Ensar Vakfi'nı savunan Aile Bakanı çark etti", "Karaman'daki taciz olayında iğrenç detaylar", "Tecavüzcü ögretmenini 14 yıl sonra tutuklattı", "Karaman'daki çocuk istismarında yeni iddialar", "Ensar Vakfi'ndan itiraf gibi istismar açıklaması", "Karaman'da 'cinsel istismar' davası başliyor", "Ensar Vakfi'nın vukuatı bitmiyor!", "Rezil tablo!”, "Karaman sapığı Muharrem Büyüktürk kaç yll yatacak?"

Haber başlıklarında "taciz", "tecavüz" ve "Ensar Vakfi" ifadelerinin beraber kullanıldığı ve bu yöntemle bir özdeşleştirme çabasının olduğu görülmektedir.

Haber metinlerine bakıldığında ise, ilk haber, Rahşan GÜLŞAN' a ait köşe yazısı olup bu yazıda doğrudan Ensar Vakfı ve bu vakfı savunanlar ve hatta bu vakıf üzerinden siyasi bir partinin hedef alındığ 1 görülmektedir. Diğer haberlere de genel olarak bakıldığında failin isim ve soy ismi açıkça belirtilmiş failin yüzünü net gösteren bir fotoğraf kullanılmıştır. Failin Karaman'da bir ilkokulda öğretmen olduğu belirtilmiş̧ir. Mağdurlarla ilgili erkek çocuk ve 10 kişi olmaları dışında hiçbir bilgi ve fotoğrafa yer verilmemiştir. Olayın Ensar vakfi ve KAİMDER"e bağlı evlerde yaşandığı belirtilmiştir. Ensar Vakfı ve KAİMDER'in adına haberlerde sıkça yer verilmiştir. Haber

4 https://www.yeniakit.com.tr/haber/chp-otobusunde-cinsel-saldiri-13-yasindaki-424874.html

5 https://www.yeniakit.com.tr/haber/chp-otobusundeki-skandal-buyuyor-425676.html 
başlıklarının çoğunda doğrudan "Ensar Vakfı" ifadesi kullanılması hedefin vakıf olduğu intibaını vermekte ve bu ifade çocuk cinsel istismarını geri planda bırakmaktadır. Dolayısıyla haberlerde Vakfı suçlayıcı ve etiketleyici bir dil kullanılmış, suçtan ve yaşanılan olaydan çok olayın geçtiği mekân ve mekânın aidiyetine vurgu yapılmıştır. Ayrıca haber metinleri dikkatle incelendiğinde sadece Ensar Vakfi'nın değil onunla beraber onun temsil ettiği düşünülen dini eğitim, bu tür eğitimi veren kurumların ve değerlerin hedefe konulduğu açıkça ortaya çıkmaktadır.

Cumhuriyet Gazetesi: : "Ensar Vakfi + taciz olayı + Cumhuriyet" ifadeleriyle Google'da yaptığımız taramada on dört tane haberin yapıldığı görülmüştür. Bunlar:

"Ensar Vakfi'yla anılan tecavüz skandalına yayın yasağı”, “Ensar Vakfi'yla anılan tecavüz skandalina 350 yll hapis istemi", "Ensar Vakfi'nin tacizci hocasina 600 yll istendi", "Aile Bakanı'na bak...,Bir kere olması karalamak için gerekçe olamaz"”, "Bilal Erdoğan: Eşimden sonra en çok Ensar Vakfi'yla görüşüyorum”, "Tecavüz skandallyla anılan Ensar Vakfi'na yumurtalı protesto", "Ensar'da yeni skandal", "'Değerli' çocuklar cinsel tacizle adını duyuran Ensar'a emanet", "Ensar'la bağlantısin itiraf eden tecavüzcü ögretmene 508 yll ceza verildi", "Karaman'da Ensar'dan sonra ikinci skandal", "Tecavüze değil haberine tahammülleri yok", "Ensar Vakfi sapı̆ğ cinsel istismar için cami lojmanı kiralamış", "AKP'nin çocuk istismarları ile sinavi... Erdoğan Ensar ve Adlyaman Gerger ile de yüzleşecek mi?", "Taciz vakfi"

Haber başlıklarına bakıldığında genel olarak taciz, tecavüz, skandal ve istismar kelimelerinin doğrudan "Ensar Vakfi" ve "AK Parti" kelimeleri ile beraber ve ilişkili bir şekilde kullanılarak bir özdeşleşme yaratılmaya çalışıldığı görülmektedir. Yine haber başlıklarında olayın kendisinden çok sanığın aidiyeti ve olayın meydana geldiği mekânın aidiyetinin ön plana çıkarıldığı dikkat çekmektedir. Hatta başka taciz vakaları haberleri verilirken dahi bu olayın metnin içerisinde yer aldığı ve aidiyetlere vurgu yapıldığı görülmektedir.

Haber metinlerine bakıldığında ise; bazı haberlerde Ensar Vakfı'nın çeşitli kamu kurumları ile yapmış olduğu işbirliklerinin eleştiri konusu yapıldığı ve özellikle bu tür işbirlikleri sonucu Milli eğitimin dinselleştirildiği, dinci vakıfların yurtlarında ve tarikat kurslarında peş peşe cinsel istismar ve tecavüz olaylarının yaşandığı iddia edilmiştir.

Ayrıca bu haberlerde doğrudan iktidar ve Cumhurbaşkanının hedef alındığı görülmektedir. Haber içeriklerinde AK Parti'nin istismar konusunda sabıkasının kabarık olduğu iddia edilmiş ve olay mahkeme tarafında rekor ceza ile sonuçlandırılmasına rağmen "Ensar Vakfi'ndaki 45 çocuğun istismarının üzeri örtüldü” alt başlı̆̆ıyla farklı bir algı yaratılmaya çalışıldığı dikkat çekmektedir.

Tüm bu haberlerde failin kimliğiyle ilgili bilgi verilmemiş. Failin yüzünün bulanık olduğu bir fotoğraf kullanılmıştır. Failin öğretmen olduğu belirtilmiştir. Mağdurlarla ilgili erkek çocuk ve 10 kişi olmaları dışında hiçbir bilgi ve fotoğrafa yer verilmemiştir. Olayın Ensar vakfi ve KAİMDER' 'e bağlı evlerde yaşandığı hem başlıklarda hem de içerikte sık sık belirtilmiştir.

Yeni Şafak Gazetesi : "Ensar Vakfi + taciz olayı + Yeni Şafak" ifadeleriyle Google'da yaptığımız taramada beş tane haberin yapıldığı görülmüştür. Bunlardan iki tanesi köşe yazısı diğerleri ise haber olarak yer almaktadır. Bunlar:

"Ensar Vakfinı idam edelim", "Mesele Ensar Vakfi değil, anlamadın mı?”, "Ensar Vakfi Başkanı Dilberoğlu: Bu kişi idam edilmeli", "Ensar Vakfi'ndan Kılıçdaroğlu' na cevap", "Ensar Vakfi'ndan karara dair ilk açıklama", "Ahlaki meseleleri gayri ahlaki bir dil ile konuşamayız!"

Haber başlıklarına bakıldığında daha çok Ensar Vakfi'nı ve benzeri kurumları taciz ve istismar olayları üzerinden hedef alan haberler karşı bir tepkinin varlığı dikkat çekmektedir.

Haber metinlerine bakıldığında ise; yaşanılan olayın kabul edilemez olduğunun vurgulandığı bununla beraber bu ve benzeri olaylar üzerinden din ve dini değerler ve bunları 
sahiplenen kişi, kurum ve kuruluşların hedefe konulduğu ve bunların çocuk taciz ve tecavüzcüsü olduklarına dair bir algı yaratılmaya çalışıldığı iddiası detaylı bir şekilde ele alınmaktadır.

Bütün bu haber ve yazıların ortak noktası davanın siyasileştirildiği, davaya müdahil olanların sanığın cezalandırılmasından ziyade olayı gündemde tutup bu vesileyle başka gündemler oluşturma ve farklı algılar yaratma iddiasıdır. Yine haber ve yazılarda işlenen diğer bir ortak nokta da yaşanılan olayın, işlenen suçun asla tasvip edilmediği, mahkeme sürecinin işletilip sanığın en ağır cezaya çarptırılmasının talep edilmesidir.

Yeni Akit: "Ensar Vakfi + taciz olayı + Sözcü" Google'da yaptığımız taramada ifadeleriyle Google'da yaptığımız taramada dokuz tane haberin yapıldığı görülmüştür.

"Ensar Vakfi Başkanı sessizliğini bozdu!”, "Ensar Vakfi'nı idam mi edelim?”, "Ensar Vakfi Başkanı Dilberoğlu'ndan şer cephesinin yalanlarına sert tepki", "Sol faşistlerden Ensar Vakfi'na hain saldırı", "Ensar Vakf göz bebeğimizdir, yedirmeyiz!", "Ensar Vakfi'ndan açılama: O kişsiyle irtibatımı bulunmuyor", "Linç kampanyasına tepki, Ensar Vakfi'na destek!", "Tecavüzcü Erol Gülen CHP'li çıktı! Kemalist sol kesim sessizliğe büründü”, Karaman'daki sapı̆̆ın adı niye gizleniyor?"

Haber başlıkları değerlendirildiğinde, özellikle Ensar Vakfi'nı koruyucu bir dilin kullanıldığı görülmektedir. Yeni Şafak gazetesi ile aynı paralelde atılan başlıklarda farklı olarak karşı suçlama ve iddiaların varlı̆̆ 1 da dikkat çekmektedir. Özellikle bazılarının, Karaman'da ki taciz olayı dolayısıyla Ensar Vakfı'nı hedef alan kişi, kurum ve medya organlarına birer tepki olarak yayınlanan haberlerin içeriklerinde de benzer ifadeler yer almaktadır.

Haber metinlerinde Ensar Vakfı yetkililerinin taciz olayı karşısında ki tepkileri ve haklarında ki iddialara yönelik cevapları yanında bazı kişi ve kurumların Ensar Vakfı'na destek mesajlarına da yer verildiği görülmektedir. İçeriklerde de Yeni Şafak gazetesi gibi taciz olayının bir araç olarak kullanıldığı ve bu araç üzerinden Ensar Vakfı, benzer şekilde dini eğitim veren kurum ve kuruluşlar ve bunların temsil ettiğini düşündükleri değerlere saldırıldığg ve bunların küçük düşürüldüğü iddiaları yer almaktadır. İçeriklerde sanık ve mağdurlarla ilgili bilgilerin yer almadığı dikkat çekmektedir.

\section{3)Nesin Vakfı Taciz Olayı}

Sözcï Gazetesi: "Nesin vakfi + taciz olayı + Sözcü" ifadeleriyle Google'da yaptığımız taramada sadece bir tane haberin yapıldığı görülmüştür.

“Aziz Nesin Yapsa Yine Susmayzz”

Başlıkta kapalı bir ifade kullanılmış ve olayın ne olduğuna dair herhangi bir işarete yer verilmemiştir. Fakat cümleden söz konusu olayın kabul edilmediği anlaşılmaktadır.

Rahşan GÜLŞAN'ın kaleme aldığı yazıda, Aziz Nesin ve Nesin Vakfi'na övgü dolu, vakfı destekler nitelikte cümleler kullanılmış, olayın tamamen yalan olduğu ileri sürülmüştür. Haber metninde Ensar Vakfi'nda gerçekleşen istismar haberi öne çıkarılmış, bu vakıfta yaşanan olayı temize çıkarmak için Aziz Nesin ve Çağdaş Yaşamı Destekleme Derneği'nde de aynı olaylar oluyor algısı yaratılmaya çalışıldığını ve "yandaş medya"nın Ensar Vakfını koruduğu öne sürülmüştür. "Hiçbir yazımda Ensar'ı suçlamadım. Asıl mesele vakıfta yaşanan olaydan hiçbir yöneticinin "sözde" haberi olmaması. Hükümetin haberi olup olmadığına bakmak yerine Ensar Vakfı'nı savunmaya soyunmuş olması" cümleleri ile hükümetin taraflı davrandığı ve olayın kapatılmaya çalışıldığı vurgulanmıştır. Nesin Vakfı ve Nesin Vakfi ile benzer görüşe sahip olan destekleyenler "Laik kitle" etiketiyle etiketlenmiştir. "Tabi ki çocuklar dini öğrensin, güzel ahlaklı olsun diye bu kuruma yollanan öğrencilerin başına böyle bir olayın gelmesi de fena bir ironi" cümleleriyle de din algısına vurgu yapılmış, bu kurumları suçlayıcı ve eleştirel bir dil kullanılmıştır. 
Bu köşe yazısı dışında olayla ilgili herhangi bir habere rastlanmamıştır. Köşe yazısının içeriğinde olaya, faile ve mağdura dair hiçbir bilgi ve fotoğrafa yer verilmemiştir.

Cumhuriyet Gazetesi: "Nesin vakfi + taciz olay 1 + cumhuriyet" ifadeleriyle Google'da yaptığımız taramada sadece bir tane haberin yapıldığı görülmüştür.

“Ensar Vakfi'nı yalan haberlerle savundu: Bu olay Aziz Nesin Vakfi ve ÇYDD'de de oldu”

Haber başlığında olayın ne olduğu ifade edilmemiş aksine muğlak bırakılmıştır. Yine başlıkta doğrudan Nesin Vakfı'nda yaşandığı iddia edilen taciz olayı reddedilmiştir.

$\mathrm{Bu}$ haberin içeriğinde olayın 2007 tarihinde yaşanması ve mağdurun kız çocuğu olması dışında hiçbir bilgiye yer verilmemiştir. Haberin devamında "Onlarca çocuğun tecavüze uğradığı Ensar Vakfı dernek başkanı kendisini aklamak için yalan üstüne yalan söylüyor. Ensar Vakfı başkanı Cenk Dilberoğlu bu seferde ÇYDD ve Nesin Vakfina iftira attı." cümleleriyle iddialar tamamen yalanlamış olayın iftira olduğu ve Ensar Vakfı'nın kendini temize çıkarmak için iftira attığ dile getirilmiştir. Cenk Dilberoğlu'nun A habere konuştuğu vurgulanmış, Vakıf Başkanı Ali Nesin'in iddia edilen olayın doğru olmadığına dair savunmasına yer verilmiştir. Dilberoğlu'nun kendini savunmak için Nesin Vakfı ve ÇYDD’nin adını kullandığını dile getirilmiş ve Nesin Vakfi'nı savunucu bir dil kullanılmıştır.

Yeni Şafak Gazetesi: “Nesin vakfı + taciz olayı + Yeni Şafak” ifadeleriyle Google'da yaptığımız taramada sadece iki tane haberin yapıldığı görülmüştür. Bunlar:

"Yurtta Eğitmen Tecavüzü", "Evcilik oyununu biraz abartmışlar”

Herhangi bir aidiyet ifadesi barındırmayan başlıklarla verilen haber metinlerinde ise öncelikle olayın nasıl ortaya çıktığı anlatılmaktadır. Ali Nesin'in olayla ilgili açıklamasında kullandığ1 "Evcilik oyununu biraz abartmışlar" cümlesi ile iğneleyici bir dil kullanıldığ1 görülmektedir. Bu haberde ayrıca Ali Nesin'in iddialar karşısında ki savunması ve bu iddiaların yalan olduğuna dair ifadelerine yer verilmiştir.

Haber metinlerine bakıldığında ise; bu olay ele alınırken faillerle ilgili bilgiye yer verilmemiş ayrıca mağdurun 14 yaşında annesi tarafindan vakfa bırakılan bir kız çocuğu olduğu dışında hiçbir bilgiye de aynı şekilde yer verilmemiştir. Mağdur ve faile ait hiçbir görsel kullanılmamış bunun yerine Ali Nesin'in röportaj verdiği bir görsel kullanılmıştır.

Yeni Akit Gazetesi: "Nesin vakf1 + taciz olayı + Yeni Akit" ifadeleriyle Google'da yaptı̆̆ımız taramada dört tane haberin yapıldığı görülmüştür. Bunlar:

"Vakfinda çocuklara tecavüz edilen Ahmet Nesin vatandaşlıktan çılkıyor", "İşte 'laikçi badeciler'in sahip olduğu kirli zihniyetin kabarık 'suç' dosyası!", "Karaman' ’n koyunu, sonra çıkar oyunu!", "Akit muhabiri Melis Alphan'ı rezil etti!"

Haber başlıklarında doğrudan Nesin Vakfi'nın ve temsil ettiği düşünülen "laikçi” kesimin hedef alındığ 1 görülmektedir. Hatta aslında konusu çok farklı olan bir haberde başlığın doğrudan tecavüz ile Nesin vakfinı özdeşleştirilecek şekilde kullanıldığı görülmektedir. Aynı haber metni içerisinde alt başlık olarak "Nesin Vakfi'nda çocuklara tecavüz" ifadesi kullanılmış ve başka yayın organlarından alınan haberlerle algı güçlendirilmeye çalışılmıştır.

Haber metinlerine bakıldığında ise; özellikle Ensar Vakfi'na yönelik suçlamalarda bulunan kişilerin "laikçi badeciler" olarak nitelendirilip bunların sahip oldukları zihniyetin sicilinin kadına ve çocuğa cinsel istismar, şiddet ve taciz olayları ile dolu olduğu çeşitli örneklerle iddia edilmiştir.

\section{Değerlendirme ve Sonuç}

Medya/Kitle iletişim araçları günümüz modern toplumları için hayati öneme sahip bir konuma gelmiştir. Özellikle teknolojik gelişmelerle birlikte kitle iletişimi alanında da önemli 
gelişmeler yaşanmış ve medya artık her yerden, her insanın her anında ulaşabileceği, hem öznesi hem nesnesi olabileceği bir hale gelmiştir.

Medyanın ulaşılabilir ve kolay kullanılabilir olması gerek bireysel gerekse toplumsal olaylar ve durumlarda etki gücünü ve yaygınlığını çok daha fazla artırmıştır. Toplumda meydana gelen herhangi bir olay kısa sürede gündem olmakta, insanlar yaşadıkları sosyal problemleri topluma ve toplumsal aktörlere kolayca aktarmakta ve böylece sorunlarına çözümler arayabilmekte ve zaman zaman da bunun karşılığını alabilmekteler. Fakat medyanın bu kadar etkili hale gelmesi beraberinde olumlu/olumsuz birçok sonucu doğurmuştur. Medyanın sahipliğinin tekel olabilecek şekilde bir veya birkaç elde toplanması, olayların/durumların ideolojik, siyasi, dini, milli ve kişisel birçok sebeple taraflı olarak hatta manipülasyon edilerek verilmesi olumsuz sonuçlardan belki de en önemlisidir. Özellikle toplumların hassas oldukları konularda olaylara yanlı bakış ve onları yanlı aktarım beraberinde birçok problemi de doğurmaktadır.

Konumuz açısından bakıldığında medyanın, toplumun en hassas olduğu konulardan biri olan taciz meselesine yaklaşımında da bu yanlı bakışı net bir şekilde görebilmekteyiz. Özellikle ideolojik olarak net bir duruş sergileyen farklı medya organlarının kendi ideolojilerine yakın kişi, kesim, grup ve kurumların içerisinde oldukları taciz, istismar ve benzeri olayları farklı bir tarzda ele alıp okuyucu/izleyiciye manipüle ederek aktardıkları görülmektedir.

Çalışmamızda içeriklerine baktığımız dört medya aracını ikili olarak sınıflandırdığımızda Sözcü/Cumhuriyet gazeteleri bir taraf olarak sol, CHP yanlısı ve AK Parti muhalifi olduğu, Yeni Şafak/Yeni Akit gazetelerinin ise diğer bir taraf olarak muhafazakâr, CHP karşıtı ve AK Parti yanlısı olduğu görülmektedir. Ele aldığımız olaylardan birisi CHP, birisi Nesin Vakfı diğeri ise Ensar vakfı ile ilgilidir.

Sözcü/Cumhuriyet gazetelerinin CHP ve Nesin Vakfi ile ilgili olaylara dair yaptıkları haberler sayı olarak sadece birer tanedir. İçerik olarak ise CHP ile ilgi olan olayda olayı anlatıp iddialara ve savunmalara yer vermekle yetinilmiştir. Nesin Vakfi ile ilgili olan olayın ise tamamen iftira olarak değerlendirildiği ve böyle bir şeyin yaşanmadığı iddiasının kuvvetlice seslendirildiği görülmektedir. Aynı yayın organlarının Ensar Vakfı ile ilişkili olayda ise yapmış oldukları haber sayısı yirmi beş tanedir. Bu haberlerin ortak özelliği başlıklardan başlayarak içeriğe kadar "tecavüz", "taciz", "istismar" ve skandal" ifadeleri ile Ensar Vakfı'nı özdeşleştirecek şekilde beraber kullanmalarıdır. Haber başlıklarına ve içeriklerine bakıldığında taciz olayından daha çok vakıf üzerinde durulduğu, hatta birçok haberde vakıfla yetinilmeyip O'nun temsil ettiğini düşündükleri değerleri, inançları, siyasi partileri ve diğer başka kurumları hedef aldıkları görülmektedir. Yani bu iki yayın organı Nesin Vakfı ile ilgili olayda adeta Vakfin savunuculuğunu yapmakta ve böyle bir olayın yaşanmadığını iddia etmektedirler. Aynı yayın organları Ensar Vakfı ile ilgili olayda ise adeta savcı rolüne bürünmekte ve vakfı ve beraberindekileri suçlu ilan edip ceza kesmektedir. Bu durum medyanın tarafsız olması gerektiği kabulüne aykırı bir durum ve ideolojik bir bakış açısının sonucu olarak değerlendirilebilir.

Yeni Şafak/Yeni Akit gazetelerinin CHP ve Nesin Vakfı ile ilgili olaylara dair toplam on tane haber yaptıkları görülmektedir. Bu haberlerde iki farklı bakış açısının var olduğu söylenebilir. Yeni şafak gazetesi olaylara daha objektif yaklaşırken Yeni Akit gazetesinin başlıklardan başlayarak içeriğe kadar "tecavüz", "taciz", "istismar" ve skandal” ifadeleri ile Nesin Vakfi ve CHP'ni özdeşleştirecek şekilde beraber kullandığı görülebilir. Ensar Vakfı ile ilgili haberde ise her iki yayın organı da olayı kınayıcı bir dil kullanmalarına rağmen Ensar Vakfı'nı koruyucu bir tavır takındıkları söylenebilir. Özellikle karşıt grup, kurum ve yayın organlarının bu olay üzerinden Ensar Vakfı ve onunla beraber dini kurum ve değerlere de saldırdıkları iddiasının sık sik dile getirildiği görülmektedir. Yani bu iki yayın organı Ensar Vakfı ile ilgili olayda adeta Vakfın savunuculuğunu yapmakta ve bu olayın suistimal edildiğini iddia etmektedirler. Özellikle Yeni Akit gazetesi CHP ve Nesin Vakfi ile ilgili olayda ise adeta savcı rolüne bürünmekte ve vakfı ve beraberindekileri suçlu ilan edip ceza kesmektedir. Bu durum da aynı şekilde medyanın tarafsız 
olması gerektiği kabulüne aykırı bir durum ve ideolojik bir bakış açısının sonucu olarak değerlendirilebilir.

\section{Kaynakça}

Alpaslan, A. H. (2014). Çocukluk döneminde cinsel istismar. Kocatepe tıp dergisi, 15(2), 194-201.

Altiparmak, S., Yildirim, G., Yardimci, F., \& Ergin, D. (2013). Annelerden alınan bilgilerle çocuk istismar1 ve etkileyen etkenler. Anatolian Journal of Psychiatry/Anadolu Psikiyatri Dergisi, 14(4), 354-361, https://doi.org/10.5455/apd.39819

Ayvaz, M. ve Aksoy, M. C. Çocuk İstismarı Ve İhmali: Ortopedik Yönleri. Acta Medica, 35.1: 2733, https://doi.org/10.14527/9786052417119.09

Aziz, A. (2010). İletişime Giriş, Genişletilmiş 2. Baskı, İstanbul: Hiperlink Yayınları

Bilginer, Ç., Hesapçioglu, S. T., \& Kandil, S. (2013). Çocukluk Çă̆ı Cinsel İstismarı: Mağdur ve Sanık Açısından Çok Yönlü Bakış, Düşünen Adam, 26(1), 55-64. https://doi.org/10.5350/dajpn2013260106

Binark, M. (2007). Yeni Medya Çalışmaları, Ankara: Dipnot Yayınları

Birleşmiş Milletler Çocuk Hakları Sözleşmesi

Bozkanat, E. (2013). Gündem Kurma Perspektifinden Algı Yönlendirme: Alkol Düzenlemesi Yasası Örneği, Yayınlanmamış Yüksek Lisans Tezi, Gazi Üniversitesi / Sosyal Bilimler Enstitüsü, Ankara

Chomsky, N. Ve Herman, E. S. (2012). Rızanın İmalatı, Çev. Abadoğlu, E., BGST Yayınları, 2. Bask1

C1lızoğlu, G. (2011). Kitle İletişim Araçlarında Yer Alan Kurgusal Sosyal Mesajlar: Televizyon Dizilerinde Kitleselleştirilen Değerlere Yönelik Bir Analiz. Selçuk Üniversitesi İletişim Fakültesi Akademik Dergisi, 6(4), 90-100, https://doi.org/10.18094/si.86985

Çeçen, A. R. (2007). Çocuk cinsel istismarı: Sıklığı, etkileri ve okul temelli önleme yolları. Uluslararası Insan Bilimleri Dergisi, 1, 1-17.

Çocuk istismarına yönelik rapor, 2016, İMDAT | Şiddeti Önleme ve Rehabilitasyon Derneği \& ASUMA | Acıbadem Üniversitesi Suç ve Şiddetle Mücadele Uygulama ve Araştırma Merkezi

Çocuk Koruma Kanunu (5395 Say1l1)

Danah. M.Boyd, \&, N. B. Ellison, (2007). Social Network Sites: Definition, history, and scholarship. Journal of Computer-Mediated Communication, 13(1), article 11. http://jcmc.indiana.edu/vol13/issue1/boyd.ellison.html

Demirel, S. D. (2018). Dijital Medyada Haber Üretim Sürecinde Okuyucu Odakl1l1k. Journal of International Social Research, 11(55), https://doi.org/10.17719/jisr.20185537253

Doğrucan A. ve Yıldırım Z. (2011). Yazılı Basında Çocuk İstismarı Haberlerinin İncelenmesi (Cumhuriyet, Hürriyet, Posta, Sabah, Yeni Şafak ve Zaman Gazeteleri Örneğinde), Uşak Üniversitesi Sosyal Bilimler Dergisi, 4/2, 176-194, https://doi.org/10.12780/uusbd98

Erkman, F. (1991). Çocukların duygusal Ezimi. Çocukların Kötü Muameleden Korunması I. Ulusal Kongresi, Ankara, (s 163). 
Finkelhor, D., \& Browne, A. (1985). The traumatic impact of child sexual abuse: A conceptualization. American Journal of orthopsychiatry, 55(4), 530-541, https://doi.org/10.1111/j.1939-0025.1985.tb02703.x

Gökçe, O. (2006). İçerik Analizi; Kuramsal ve Pratik Bilgiler, Siyasal Kitabevi.

Güler, N., Uzun, S., Boztaş, Z., \& Aydoğan, S. (2002). Anneleri tarafindan çocuklara uygulanan duygusal ve fiziksel istismar/ihmal davranışı ve bunu etkileyen faktörler. Cumhuriyet Üniversitesi Tıp Fakültesi Dergisi, 24(3), 128-134.

Güner, Ş. İ., Güner, S., \& Şahan, M. H. (2010). "Çocuklarda Sosyal Ve Medikal Bir Problem; İstismar". Van Tip Dergisi, 17(3), 108-113.

Güneş, S. (2006), Enformasyon Toplumunun Putlar (1.Basım), Ankara: Hece Yayınları,

İşeri, E. (2008). Cinsel istismar. Çocuk ve ergen psikiyatrisi temel kitabl, 1, 470-476.

Kanak, M (2011). 0-10 Yaş Cinsel İstismarının Sanal Medyadaki Yansıması, Yayımlanmamış Yüksek Lisans Tezi, İnönü Üniversitesi Sosyal Bilimler Enstitüsü, Malatya.

Kara, B., Biçer, Ü., ve Gökalp, A. S. (2004). Çocuk istismarı, Çocuk Sağglığı ve Hastalıkları Dergisi 47.2, 140-151.

Kocadaş, B. (2002). Görsel Medya ve Şiddet Kültürü (Orta Öğrenim Çağı Gençliğinin Şiddet Eğiliminde Görsel Medyanın Etkisi)-Malatya İli Uygulaması-, Yayımlanmamış Doktora Tezi, İnönü Üniversitesi Sosyal Bilimler Enstitüsü, Malatya.

Olgun, C. K. (2008). "Nitel Araştırmalarda İçerik Analizi Tekniği”, Sosyoloji Notları, OcakŞubat-Mart (4), Nisan-Mayıs-Haziran (5), Ankara

Özdemir, E. (2012). Çocuk İstismarı Haberlerinin Yazılı Basında Sunumu. Yayınlanmamış Yüksek Lisans Tezi, Gazi Üniversitesi Sosyal Bilimler Enstitüsü, Ankara

Özerkan Ş. (2001). Medya Dil ve ideoloji, İletişim Fakültesi Dergisi, İstanbul: Martı Yayınları

Pelendecioğlu, B.\& Bulut, S. (2009). Çocuğa yönelik aile içi fiziksel istismar. Abant İzzet Baysal Üniversitesi Eğitim Fakültesi Dergisi,9(1), https://doi.org/10.17240/aibuefd.2015.15.05000128646

Sağlam, M. ve Aral, N. (2017). "Tarihsel Süreç İçerisinde Çocuk ve Çocukluk Kavramları". Çocuk ve Medeniyet Dergisi, 1(2), 51-62, https://doi.org/10.36731/cg.472028

Şimşek, S., \& Cenkseven-Önder, F. (2011). Ergenlerde davranış problemlerinin, anne-babadan ve öğretmenlerden algılanan duygusal istismar açısından incelenmesi. Ilköğretim Online, 10(3), 1123-1137.

Taner, Y., \& Gökler, B. (2004). Çocuk istismarı ve ihmali: Psikiyatrik yönleri. Acta Medica, 35(2), $82-86$

Tıraşçı, Y. ve Gören, S. (2007). "Çocuk istismarı ve ihmali”. Dicle Tip Dergisi, 34(1), 70-74, https://doi.org/10.14527/9786052417119.09

Yurdigül, Y., \& Zinderen, İ. E. (2012). Yeni Medyada Haber Dili (Ayşe Paşalı Olayı Üzerinden Geleneksel Medya Ve İnternet Haberciliği Karşılaştırması). The Turkish Online Journal of Design Art and Communication, 2(3), 81-91, https://doi.org/10.7456/10203100/010

Yavuzer, H. (1995). Ana Baba ve Çocuk, İstanbul: Remzi Kitabevi 


\section{İnternet Kaynakları}

http://www.tdk.gov.tr/index.php?option=com_bts\&arama=kelime\&guid=TDK.GTS.5c78202156f5 22.60120595 (E.T. 28.02.19)

http://www.iletisimvediplomasi.com/medya-okuryazarligi-prof-dr-zakir-avsar/

https://www.sozcu.com.tr/2018/gundem/chpli-eski-yonetici-tacizden-tutuklandi-2240383/

(E.T. 24.10.2019)

http://www.cumhuriyet.com.tr/haber/turkiye/931895/CHP_tacizin_uzerini_ortmedi_partiden_ihra c_etti.html (E.T. 24.10.2019)

https://www.yenisafak.com/gundem/chpli-yonetici-cocuga-taciz-iddiasiyla-tutuklandi-3153217

(E.T. 24.10.2019)

https://www.yeniakit.com.tr/haber/chp-otobusunde-cinsel-saldiri-13-yasindaki-424874.html 24.10.2019)

https://www.yeniakit.com.tr/haber/chp-otobusundeki-skandal-buyuyor-425676.html 24.10.2019)

https://www.yeniakit.com.tr/haber/chpli-sapik-cocuga-tacizden-tutuklandi-427083.html 24.10.2019)

(E.T.

(E.T. www.sozcu.com.tr/2016/yazarlar/rahsan-gulsan/tecavuze-ugrayan-bebeler-mi-ensar-vakfimi-korunmaya-muhtac-1147387/ (E.T. 24.10.2019)

https://www.sozcu.com.tr/2016/gundem/ensar-vakfini-savunan-aile-bakani-cark-etti-1150710/ (E.T. 24.10.2019)

https://www.sozcu.com.tr/2016/gundem/karamandaki-taciz-olayinda-igrenc-detaylar-1151143/ (E.T. 24.10.2019)

https://www.sozcu.com.tr/2016/gundem/tecevuzcu-ogretmenini-17-yil-sonra-tutuklatti-1151725/ (E.T. 24.10.2019)

https://www.sozcu.com.tr/2016/gundem/karamandaki-cocuk-istismarinda-yeni-iddialar-1154287/ (E.T. 24.10.2019)

https://www.sozcu.com.tr/2016/gundem/ensar-vakfindan-istismar-itirafi-1190979/

(E.T. 24.10.2019)

https://www.sozcu.com.tr/2016/gundem/karamanda-cinsel-istismar-davasi-basliyor-1192543/ (E.T. 24.10.2019)

https://www.sozcu.com.tr/2016/gundem/ensar-vakfinin-vukuati-bitmiyor-1154313/ 24.10.2019)

https://www.sozcu.com.tr/2016/yazarlar/necati-dogru/rezil-tablo-1164317/ (E.T. 24.10.2019)

https://www.sozcu.com.tr/2016/gundem/karaman-sapigi-muharrem-buyukturk-kac-yil-yatacak1194048/ (E.T. 24.10.2019)

http://www.cumhuriyet.com.tr/haber/turkiye/498611/Ensar_Vakfi_yla_anilan_tecavuz_skandalina_ yayin_yasagi.html (E.T. 24.10.2019)

http://www.cumhuriyet.com.tr/haber/turkiye/499193/Ensar_Vakfi_yla_anilan_tecavuz_skandalina_ 350_yil_hapis_istemi.html (E.T. 24.10.2019)

http://www.cumhuriyet.com.tr/haber/turkiye/502145/Ensar_Vakfi_nin_tacizci_hocasina_600_yil_i stendi.html (E.T. 24.10.2019)

Turkish Studies - Social, 15(1) 
http://www.cumhuriyet.com.tr/haber/turkiye/502587/Aile_Bakani_na_bak..._Bir_kere_olmasi_ka ralamak_icin_gerekce_olamaz_html (E.T. 24.10.2019)

http://www.cumhuriyet.com.tr/haber/turkiye/503049/Bilal_Erdogan_Esimden_sonra_en_cok_Ens ar_Vakfi_yla_gorusuyorum.html (E.T. 24.10.2019)

http://www.cumhuriyet.com.tr/haber/turkiye/504564/Tecavuz_skandaliyla_anilan_Ensar_Vakfi_na _yumurtali_protesto.html (E.T. 24.10.2019)

http://www.cumhuriyet.com.tr/haber/turkiye/504770/Ensar_da_yeni_skandal.html

(E.T. 24.10.2019)

http://www.cumhuriyet.com.tr/haber/siyaset/709575/_Degerli_cocuklar_cinsel_tacizle_adini_duy uran_Ensar_a_emanet.html (E.T. 24.10.2019)

http://www.cumhuriyet.com.tr/haber/turkiye/518726/Ensar_la_baglantisini_itiraf_eden_tecavuzcu_ ogretmene_508_yil_ceza_verildi.html (E.T. 24.10.2019)

http://www.cumhuriyet.com.tr/haber/turkiye/725358/Karaman_da_Ensar_dan_sonra_ikinci_skanda 1.html (E.T. 24.10.2019)

http://www.cumhuriyet.com.tr/haber/turkiye/793230/Tecavuze_degil_haberine_tahammulleri_yok. html (E.T. 24.10.2019)

http://www.cumhuriyet.com.tr/haber/turkiye/584734/Ensar_Vakfi_sapigi_cinsel_istismar_icin_ca mi_lojmani_kiralamis.html (E.T. 24.10.2019)

http://www.cumhuriyet.com.tr/haber/turkiye/930278/AKP_nin_cocuk_istismarlari_ile_sinavi..._Er dogan_Ensar_ve_Adiyaman_Gerger_ile_de_yuzlesecek_mi_.html (E.T. 24.10.2019)

http://www.cumhuriyet.com.tr/haber/siyaset/514293/Taciz_vakfi.html (E.T. 24.10.2019)

https://www.yenisafak.com/yazarlar/ismailkilicarslan/ensar-vakfiuni-idam-edelim-2027591

(E.T. 24.10.2019)

https://www.yenisafak.com/yazarlar/aydinunal/mesele-ensar-vakfi-degil-anlamadin-mi-2027725 (E.T. 24.10.2019)

https://www.yenisafak.com/gundem/ensar-vakfi-baskani-dilberoglu-bu-kisi-idam-edilmeli2439326 (E.T. 24.10.2019)

https://www.yenisafak.com/gundem/ensar-vakfindan-kilicdarogluna-cevap-2451998 24.10.2019)

https://www.yenisafak.com/gundem/ensar-vakfindan-karara-dair-ilk-aciklama-2454572 24.10.2019)

https://www.yenisafak.com/yazarlar/fatmabarbarosoglu/ahlaki-meseleleri-gayri-ahlaki-bir-dil-ilekonuamayiz-2028076 (E.T. 24.10.2019)

https://www.yeniakit.com.tr/haber/ensar-vakfi-baskani-sessizligini-bozdu-164288.html

(E.T. 24.10.2019)

https://www.yeniakit.com.tr/haber/ensar-vakfini-idam-mi-edelim-153325.html (E.T. 24.10.2019)

https://www.yeniakit.com.tr/haber/ensar-vakfi-baskani-dilberoglundan-ser-cephesinin-yalanlarinasert-tepki-150152.html (E.T. 24.10.2019)

https://www.yeniakit.com.tr/haber/sol-fasistlerden-ensar-vakfina-hain-saldiri-150300.html

(E.T. 24.10.2019) 
https://www.yeniakit.com.tr/haber/ensar-vakfi-goz-bebegimizdir-yedirmeyiz-151461.html (E.T. 24.10.2019)

https://www.yeniakit.com.tr/haber/ensar-vakfindan-aciklama-o-kisiyle-irtibatimiz-bulunmuyor146932.html (E.T. 24.10.2019)

https://www.yeniakit.com.tr/haber/linc-kampanyasina-tepki-ensar-vakfina-destek-157329.html (E.T. 24.10.2019)

https://www.yeniakit.com.tr/haber/tecavuzcu-erol-gulen-chpli-cikti-kemalist-sol-kesim-sessizligeburundu-850481.html (E.T. 24.10.2019)

https://www.yeniakit.com.tr/yazarlar/ali-karahasanoglu/karamandaki-sapigin-adi-niye-gizleniyor14590.html (E.T. 24.10.2019)

https://www.sozcu.com.tr/2016/yazarlar/rahsan-gulsan/aziz-nesin-vakfi-yapsa-yine-susmayiz1156301/ (E.T. 24.10.2019)

http://www.cumhuriyet.com.tr/haber/turkiye/504930/Ensar_Vakfi_ni_yalan_haberlerle_savundu_ Bu_olay_Aziz_Nesin_Vakfi_ve_CYDD_de_de_oldu.html (E.T. 24.10.2019)

https://www.yenisafak.com/gundem/yurtta-egitmen-tecavuzu-23622 (E.T. 24.10.2019)

https://www.yenisafak.com/gundem/evcilik-oyununu-biraz-abartmislar-23762 (E.T. 24.10.2019)

https://www.yeniakit.com.tr/haber/vakfinda-cocuklara-tecavuz-edilen-ahmet-nesin-vatandasliktancikiyor-855955.html (E.T. 24.10.2019)

https://www.yeniakit.com.tr/haber/iste-laikci-badecilerin-sahip-oldugu-kirli-zihniyetin-kabariksuc-dosyasi-901560.html (E.T. 24.10.2019)

https://www.yeniakit.com.tr/yazarlar/ali-karahasanoglu/karamanin-koyunu-sonra-cikar-oyunu14555.html (E.T. 24.10.2019)

https://www.yeniakit.com.tr/haber/akit-muhabiri-melis-alphani-rezil-etti-156703.html

(E.T. 24.10.2019) 